\title{
IRYNA PROCYK
}

ORCID: 0000-0001-8472-0141

Katedra Ukraińskiego Językoznawstwa Stosowanego,

Uniwersytet Narodowy im. Iwana Franki we Lwowie

\section{Zmiana retoryki ukraińskich kibiców piłkarskich podczas społeczno- -politycznych wydarzeń na Ukrainie w latach 2013-2016}

\author{
...20 000 zagubionych $\mathrm{w}$ ciemności gardeł \\ wrzeszczących \\ coś brutalnego i politycznie niepoprawnego, \\ ale uczciwego i zrozumiałego \\ nawet dla najbardziej oddalonych od profe- \\ sjonalnego sportu świętych.
}

Serhij Żadan, Białe koszule, czarne spodenki (Жадан 2011: 92) ${ }^{1}$

\section{Abstrakt}

W społeczeństwie ukraińskim środowisko kibiców piłkarskich postrzegane jest przeważnie negatywnie - ze względu na słowną agresję oraz ich brutalne zachowanie na stadionach i poza nimi. Na Ukrainie, podobnie jak w innych krajach europejskich, ruchy kibicowskie nigdy nie pozostawały $\mathrm{z}$ dala od polityki: zawsze podkreślały swoją tożsamość narodową, aktywnie reagowały na wydarzenia społeczno-polityczne w kraju, wyrażały agresywne nastawienie do grup deklarujących poglądy lewicowe. Zmiana tradycyjnie wrogiego zachowania w stosunku do grup kibiców drużyn przeciwnych zaszła w środowisku fanów piłki nożnej na przełomie lat 2013 i 2014, kiedy to na Ukrainie miała miejsce Rewolucja Godności. Kibice jako pierwsi wystąpili w obronie jej wartości. 13 lutego 2014 roku ukazał

${ }^{1}$ Wszystkie teksty oryginalne są przekładem autorskim. „...20000 загублених у мороці горлянок, які викрикують щось брутальне й неполіткоректне, проте чесне й зрозуміле навіть найбільш далеким від професійного спорту святим", Сергій Жадан, Білі футболки, чорні труси. 
się ich manifest pod tytułem „Od Ługańska po Karpaty kibic dla kibica - brat i przyjaciel” („Від Луганська до Карпат фанат фанату - друг і брат”). Jego założenia, ogłaszające rozejm kibiców, pozostają nienaruszone do dziś. Celem artykułu jest przedstawienie zmiany werbalnego i niewerbalnego zachowania ukraińskich kibiców piłkarskich w czasie wydarzeń społeczno-politycznych na Ukrainie w latach 2013-2016 oraz zaprezentowanie tekstów składających się na dyskurs fanów piłki nożnej - tekstów, które stały się powszechnie używanymi hasłami i piosenkami podczas Majdanu i agresji rosyjskiej w latach 2014-2016.

Słowa kluczowe: wydarzenia społeczno-polityczne na Ukrainie, kibice piłki nożnej, zachowania werbalne i niewerbalne, agresja słowna, zmiana retoryki.

Kibice piłki nożnej są postrzegani w społeczeństwie przede wszystkim negatywnie - jako grupa społeczna, której nieodłącznymi cechami są brutalne zachowanie oraz agresja słowna. Społeczeństwo spośród wszystkich właściwości tej subkultury wychwytuje to, co znajduje się na powierzchni i od razu rzuca się w oczy, tworząc w ten sposób stereotyp kibiców jako brutalnych zbirów. Takie postrzeganie ich przez opinię publiczną często wynika $\mathrm{z}$ informacji docierających $\mathrm{z}$ mediów, w tym $\mathrm{z}$ doniesień o bójkach między fanami różnych drużyn, o walkach z policją, agresywnych zachowaniach na stadionach i poza nimi, odpalaniu rac w sektorach kibiców itd. Wszystkie te cechy są właściwe zachowaniu fanatycznych kibiców piłkarskich na całym świecie.

Celem artykułu jest omówienie zmian zachowań werbalnych i niewerbalnych ukraińskich kibiców piłkarskich w czasie wydarzeń społeczno-politycznych na Ukrainie w latach 2013-2016.

Tradycyjnie fani piłki nożnej mają wśród kibiców przeciwnych drużyn przyjaciół i wrogów, czyli - według języka „szalikowców” - tak zwane kosy i zgody. Żadnym wyjątkiem nie są tutaj ukraińscy kibice, którzy prowadzą zaciekłe wieloletnie wojny. W środowisku ukraińskich fanów piłki nożnej powstały dwie grupy zrzeszające kibiców tych klubów, które pozostają z sobą w przyjaznych stosunkach, a jednocześnie mają napięte relacje $\mathrm{z}$ przedstawicielami wrogiej grupy. Pierwsza z nich obejmuje kibiców: Dynama Kijów, Dnipra Dnipro, Karpat Lwów, druga zaś: Czornomorca Odessa, Metalista Charków, Szachtara Donieck oraz Metalurga Zaporoże $^{2}$. W sytuacji gdy fani dwóch drużyn mają z sobą „kosę”, dochodzi między nimi do konfrontacji w machaczach ('ustawkach'), a także w przestrzeni dyskursywnej, w której zastosowanie znajduje retoryka walki. To powoduje, że teksty ultrasów są pełne słownictwa militarnego, na przykład: ostrzał, atak, wojna na transparenty, bitwa, bombardowanie, bomba, wojna na graffiti, zacięty wróg, mobilizacja do wyjaz$d u$, zwycięstwo, porażka, pressing, trofeum, uderzenie $e^{3}$; terminologii wojskowej używanej tutaj w kontekście sportowym, na przykład: ofensywny/defensywny wariant

2 Zgodnie z ukraińską ustawą o dekomunizacji z dnia 9 kwietnia 2016 roku miasto Dniepropietrowsk zostało przemianowane na Dnipro.

${ }^{3} \mathrm{~W}$ języku ukraińskim: артобстріл, атака, банерна війна, битва, бомбардування, бомба, графіті-війна, заклятий ворог, мобілізація на виїзд, перемога, поразка, пресинг, трофей, удар. 
gry, kontra, linia ataku/obrony, atak pozycyjny, prawa/lewa flanka, taktyka gry, obrona całkowita (totalna), sztab szkoleniowy ${ }^{4}$ oraz obraźliwych uwag kierowanych pod adresem przeciwników. Dla przykładu, kibice Dynama Kijów stosują następujące inwektywy wobec fanów Metalista Charków: Od was cuchnie! ${ }^{5}$; Zapachniało smażonym tchórzem ${ }^{6}$. Obie frazy wprost odnoszą się do ich przezwiska - tchórze/fretki. W języku rosyjskim słowo tchórz (ros. хорькu) brzmi podobnie jak nazwa miasta Charków. Nie dziwi zatem, że jedna z cech przypisanych zazwyczaj fretkom - ich zapach, została zastosowana w przezwisku kibiców Metalista. Z kolei wrogość przeciwników Dynama Kijów została zwerbalizowana w okrzyku Duś chochołów! ! (chochoły to stare przezwisko kibiców, znane jeszcze z czasów Związku Radzieckiego, kiedy to Dynamo było jedynym ukraińskim klubem mogącym realnie konkurować z moskiewskimi drużynami piłkarskimi). Ultrasi kijowskiego klubu są także autorami innej inwektywy, tym razem formułowanej pod adresem fanów Czornomorca z Odessy. Brzmi ona następująco: Chochoł się narodził - Żyd się poptakał! ${ }^{8}$. Z tego względu, że wśród mieszkańców Odessy znaczny odsetek stanowią przedstawiciele społeczności żydowskiej, kibiców Czornomorca określa się mianem Żydów.

Inną cechą szczególną wszystkich ruchów fanów piłki nożnej, zarówno na świecie, jak i na Ukrainie, jest nienawiść do przedstawicieli organów ścigania. Tradycyjną obelgą formułowaną pod adresem policji jest angielski skrót, który stał się już internacjonalizmem - A.C.A.B (All Cops Are Bastards). Skrót ten można znaleźć na murach, ogrodzeniach i ścianach domów wszystkich ukraińskich miast. W socjolekcie tutejszych kibiców wykorzystywana jest także duża liczba synonimów obraźliwych przezwisk policjantów, tj.: akaby, akabery, acab, kaszkiety, kopy, psy, męty, śmieci, nie-ludzie, pagony, rugbiści, sambiści (od sambo - 'rosyjskiej sztuki walki'), szarzy, słonie (od rosyjskiego skrótu S.L.O.N. - смерть лягавым от ножа - śmierć psom od noża), cerbery ${ }^{9}$. Odrębne sformułowania stosowane są wobec różnych jednostek policji. W odniesieniu do funkcjonariuszy Berkutu ${ }^{10}$ pojawiają się następujące nazwy: berkuty, berkuciata, gryfony, omonowcy (od ros. skrótu OMON - 'отряд милииии особого назначения', czyli 'jednostka specjalnego przeznaczenia’; oddziały Berkutu powstały na bazie radzieckich jednostek OMON-u), kosmonauci ${ }^{11}$.

${ }^{4}$ W języku ukraińskim: атакувальний/захисний варіант гри, контратака, лінія атаки/захисту, позиційна атака, правий / лівий фланг, тактика гри, тотальний захист, тренерський umaб.

${ }^{5}$ W języku ukraińskim: Bì вас mхне!

6 W języku ukraińskim: Запахло смаженим хорьком!

7 W języku ukraińskim: Дави хохлів!

8 W języku ukraińskim: Хохол народився - жид заплакав!

9 W języku ukraińskim: акаби, акабери, асав, кашкети, копи, тягаві, мєнти, мусори, недолюди, погони, регбісти, самбісти, сірі, слони, иербери.

${ }^{10}$ Jest to wyspecjalizowana jednostka milicji ukraińskiej, podległa Ministerstwu Spraw Wewnętrznych. Słowo berkut to ukraińska nazwa orła przedniego. Rozkazem MSW z dnia 25 lutego 2014 roku oddziały Berkutu zostały zlikwidowane.

11 W języku ukraińskim: беркути, беркутята, грибони, омонівиі, космонавти. 
Ukraińscy kibice piłki nożnej prawie nigdy nie dystansowali się od polityki (podobne przykłady zaangażowania politycznego można dostrzec w kręgach kibiców futbolu w Wielkiej Brytanii, Włoszech, Hiszpanii, Chorwacji, Serbii). Nawet wspomniany wcześniej podział na „przyjaciół” i „wrogów” w środowisku tutejszych kibiców oparty jest głównie na jednym kryterium — ich stosunku do klubów rosyjskich. Na przykład napięcie istniejące między ultrasami Dynama Kijów a Czornomorca Odessa i Metalurga Zaporoże dotyczy przyjaznych relacji, utrzymywanych przez te dwa ostatnie kluby z fanatykami moskiewskich drużyn. Od lat osiemdziesiątych $\mathrm{XX}$ wieku znane są przyśpiewki kijowskich kibiców, kierowane pod adresem ultrasów z rosyjskiej stolicy: Bij, bij Moskali! ${ }^{12}$. Co ciekawe, te wykonywane po rosyjsku pieśni były zawsze z zaskoczeniem odbierane przez mówiących po ukraińsku fanów z innych miast kraju. Od czasów Związku Radzieckiego często dochodziło nie tylko do meczów piłkarskich między Dynamem Kijów a drużynami moskiewskimi, przede wszystkim Spartakiem Moskwa, lecz także do gwałtownych starć zwolenników tych drużyn. W trakcie tych spotkań zawsze stosowano nadzwyczajne środki bezpieczeństwa, aby zapobiec krwawym machaczom między kibicami.

Źródeł wrogości między ukraińskimi ultrasami należy szukać również w ich poglądach politycznych, w tym w opozycji do haseł lewicowych. Prawie wszyscy ukraińscy fani piłkarscy identyfikują się z ideologią nacjonalistyczną, w wyniku czego mają napięte stosunki z lewicującymi kibicami stołecznego Arsenału. Ze względu na to, że na Ukrainie w XX wieku pod płaszczykiem tej ideologii doszło do największych zbrodni przeciwko ludzkości, kibice stają się w tym wypadku wyrazicielami pamięci pokoleń. Na przykład tradycyjnie w dzień upamiętnienia ofiar Wielkiego Głodu (lata 1932-1933) fani większości drużyn piłkarskich na znak szacunku wieszają na stadionach transparenty upamiętniające tragicznie pomordowanych. Ich treść jest następująca: Pamiętamy, Sierp i młot - śmierć i głód; Wieczna pamięć. 32-33; Wieczna pamięć ofiarom ludobójstwa, 1932-1933; Ukraina pamięta, Świat uznaje, 1932-1933'13.

Kibice przywykli do obrony honoru swojego ulubionego klubu nie tylko w formie słownej, lecz również podczas fizycznej konfrontacji z przeciwnikami. Lokalny patriotyzm, który w ich wypadku zaczyna się od miłości do ulubionego zespołu piłkarskiego ze swego miasta (Jak Ciebie nie kochać, Kijowie mój; Dniepr wielki, Dniepr - serce Ukrainy, Moja Poltawa, Połtawa - duchowa stolica; Lwów ponad wszystko!; Lwów, Lwów, tylko Lwów! $)^{14}$, przeradza się w większe uczucie - w miłość do własnego kraju (Za Ukrainę!; Wielka drużyna wielkiego państwa, Nie masz rodu ponad

12 W języku rosyjskim: Бей, бей москалей!

${ }^{13}$ W języku ukraińskim: 1932-1933. Пам'ятаємо, Серп і молот - смерть і голод, Вічна пам'ять. 32-33, Вічна пам'ять жертвам геноииду, 1932-1933. Україна пам'ятає. Світ визнає, 1932-33.

${ }^{14} \mathrm{~W}$ języku ukraińskim: Як тебе не любити, Києве мій!; Дніпро великий, Дніпро - серие україни!; Моя Полтава, Полтава - духовна столиия; Львів - понад усе!; Львів, Львів, тільки Львів!. 
ród kozacki; Ukraina ponad wszystko! $)^{15}$ i do swojego narodu (Sława narodowi) ${ }^{16}$. Sektory kibiców piłki nożnej często ozdobione są transparentami z portretami znanych Ukraińców, którzy stali się symbolami ruchu niepodległościowego (tj. Taras Szewczenko, Jewhen Konowalec, Stepan Bandera, Roman Szuchewycz), a także patriotycznymi hasłami, na przykład: Pochowajcie i wstawajcie!; Zlecimy duchem kozackim; Nic nie zatrzyma idei, której czas nadszedt; Donbas za UPA!17; Chwała niezwyciężonej armii UPA; Bandera - nasz bohater!; Ukraina albo śmierć; Wola Ukrainy albo śmierć!; Idea narodu; Sława Ukrainie! Bohaterom chwała! ${ }^{18}$.

Ukraińscy kibice futbolu są znani ze swojej aktywności obywatelskiej. Krytyczny stosunek do władzy oraz ostre słowa pod adresem elit rządzących, które pojawiają się w sloganach i na banerach ultrasów, odzwierciedlają nastroje społeczeństwa. Fani piłki nożnej natychmiast reagują na zmiany w życiu społecznym i politycznym. W swoim czasie kibice jako pierwsi wezwali do dymisji Dmytra Tabacznyka — ministra edukacji w czasach Wiktora Janukowycza, wieszając na płotach fan-sektorów banery: Tabacznyka na pal!; Precz z Tabaką! ${ }^{19}$. Z kolei ultrasi kijowskiego Dynama i lwowskich Karpat byli autorami przyśpiewki (Dziękujemy mieszkańcom Donbasu za prezydenta pedała ${ }^{20}$ ) pod adresem urzędującego wówczas prezydenta, która później stała się powszechna w całym kraju.

Nieoczekiwana dla szerokiego grona odbiorców, jednak uzasadniona i logicznie umotywowana dla zorientowanych w środowisku kibicowskim, zmiana werbalnego i niewerbalnego zachowania ukraińskich piłkarskich ultrasów miała miejsce podczas akcji protestacyjnych w Kijowie pod koniec 2013 i na początku roku 2014. Fani piłki nożnej prawie wszystkich ukraińskich klubów wykazali poparcie dla kijowskiego Majdanu, przyłączyli się do ochraniania pokojowych protestów w innych miastach, broniąc ich uczestników przed bandami „tituszek”21, a także brali udział w walkach na barykadach podczas Rewolucji Godności (Білан 2014; Процик 2014; Щур 2014).

15 W języku ukraińskim: За Україну!; Велика команда великої держави; Козацькому роду нема переводу; Україна понад усе!

${ }^{16}$ W języku ukraińskim: Слава націï!

17 Ukraińcy szanują UPA (Ukraińską Armię Powstańczą) za to, iż jej żołnierze walczyli jednocześnie z nazizmem niemieckim oraz z bolszewizmem radzieckim, przy czym walki z sowieckim wrogiem trwały aż do połowy lat pięćdziesiątych XX wieku. Dlatego UPA w świadomości Ukraińców jest symbolem patriotyzmu i wyzwolenia od panowania rosyjskiego.

${ }^{18}$ W języku ukraińskim: Поховайте та вставайте!; Рубанем козацьким духом; Німзо не зупинить ідею, час якої настав; Донбас за УПА!; Слава армії нескорених - УПА; Бандера - наш герой!; Воля України або смерть!; Ідея націі; Слава Україні! Героям слава!

${ }^{19}$ W języku ukraińskim: Табачника на палю!, Геть Табаку!

${ }^{20}$ W języku rosyjskim: Спасибо жителям Донбасса за президента пидараса!

21 „Tituszki” - pojęcie służące do opisu najemników, często z tak zwanych nizin społecznych, których władza na Ukrainie wykorzystywała do rozwiązań siłowych i udziału w masowych bijatykach. Termin pochodzi od nazwiska sportowca, dresiarza Wadyma Tituszki, który wiosną 2013 roku pobił dziennikarzy (sam napad został udokumentowany). 
13 lutego 2014 roku przedstawiciele kibiców ukraińskich zespołów piłkarskich, występujących w ekstraklasie, w pierwszej i drugiej lidze, jak również fani kilku zespołów amatorskich, podpisali manifest $\mathrm{w}$ sprawie ustanowienia rozejmu między ukraińskimi ultrasami. Jego dewizą stało się następujące stwierdzenie: Od Ługańska po Karpaty kibic dla kibica - brat i przyjaciel ${ }^{22}$. Dokument ten jest przykładem odpowiedniej percepcji i zrozumienia sytuacji w kraju w czasie, gdy jedność wszystkich Ukraińców okazała się tak potrzebna. Oto najważniejsze fragmenty oficjalnego oświadczenia ultrasów (wyróżnienia - I.P.):

My, fani ukraińskich drużyn piłkarskich, oświadczamy co następuje. W społeczeństwie ukraińskim wynikła bardzo trudna sytuacja. W szczególności, niektóre ruchy kibiców już mają problemy w swoich miastach z jednostkami „praworządności” oraz władzami lokalnymi wyłącznie dlatego, że przedstawiciele tych ruchów publicznie wyrazili swoją pokojową, obywatelską opinię, do której mają wszelkie prawo. W związku z tym uważamy, że dalsze przedłużanie wszelkiej konfrontacji między sobą to przestępstwo, które obróci się przeciwko nam samym i w końcu tylko pogorszy obecną sytuację społeczną. Biorąc pod uwagę powyższe, zdecydowaliśmy się zawrzeć rozejm między ruchami fanów różnych klubów na termin nieokreślony. Rozejm ten obowiązuje na następujących warunkach:

- wszelkie elementy działań „miejskich”, czyli spontanicznych, oraz „ustawki” są zakazane;

— zdobywanie transparentów, szalików i innych atrybutów przeciwników jest zakazane;

- obraźliwe transparenty, skandowanie przeciwko sobie lub pod adresem miast-przeciwników, zespołów-przeciwników jest zakazane;

- na trybunach konieczna jest ścisła kontrola, aby zapobiec pojawianiu się szalików obrażających drużynę przeciwników i spalonych szalików zespołów-przeciwników;

- zakazane jest tworzenie graffiti obrażających inne drużyny i ruchy, rozpowszechnianie w Internecie istniejących już [obraźliwych - I.P.] graffiti, jak również jakakolwiek wojna grafficiarska między kibicami;

- konieczna jest ścisła kontrola, której celem pozostaje wyeliminowanie jakichkolwiek konfliktów pomiędzy zwykłymi kibicami (nie szalikowcami) drużyn przeciwnych tak na wyjazdach, jak i na meczach u siebie.

Te elementy stanowią podstawę przyszłego rozejmu. Decyzję w sprawie rozejmu w całości wsparli przywódcy ruchów kibicowskich z następujących klubów piłkarskich ekstraklasy: Wołyń Łuck, Worskla Połtawa, Dynamo Kijów, Dnipro Dniepropietrowsk, Zakarpattya Użhorod, Zoria Ługańsk, Karpaty Lwów, Metalist Charków (trybuny: Południowa i Północna), Metalurg Zaporoże, Metalurg Mariupol, FK Sewastopol, Tawria Symferopol (Sektor 5 i Sektor 9), Czornomoreć Odessa, Szachtar Donieck; pierwszej i drugiej ligi: Awangard Kramatorsk, Bukowyna Czerniowce, Desna Czernihów (Chłopaki Stolicy Północnej i Ultras Desna), Dnipro Czerkasy, Energia Nowa Kachowka, Zirka Kirowograd (czerwono-żółte i żółto-zielone), Kryształ Cherson, FC Nikołajew, Nyva Ternopol, FC Aleksandria, Obołoń Kijów, Podilla Chmielnicki, Skała Stryj, Stal Ałczewsk, Stal Dniepropietrowsk, FC Sumy, Tytan Armiańsk. Ruchy kibicowskie lig amatorskich i bez klubów: Krywbas Krzywy Róg, Nyva Winnica. Te ruchy, z którymi my nie zdążliśmy lub nie możemy nawiązać kontaktu, prosimy o wsparcie naszej inicjatywy i potwierdzenie gotowości do przestrzegania rozejmu według wszystkich powyżej wymienionych punktów.

Oprócz tego uważamy, że obecnie stosunki między nami powinny być oparte na zasadzie, że przede wszystkim jesteśmy Ukraińcami. To znaczy, na pierwszym miejscu powinno być zrozumienie, zaufanie i wzajemne wsparcie. Wzywamy wszystkich ukraińskich kibiców, którzy nie

${ }^{22}$ W języku ukraińskim: Від Луганська до Карпат фанат фанату - друг і брат. 
należą do żadnych ugrupowań fanów (mówimy nie tylko o piłce nożnej), do przyłączenia się do rozejmu i odnoszenia się do siebie bez agresji, nie zważając na to, jakie przeciwieństwa będą dzieliły nasze zespoły na boiskach i stadionach sportowych. [...] Dlatego uważamy, że kontynuowanie jakiejkolwiek konfrontacji w środowisku kibicowskim będzie obecnie zbrodnią przeciwko świetlanej przyszłości Ukrainy. „Od Ługańska po Karpaty kibic kibicowi - brat i przyjaciel”. Chwała Ukrainie! ${ }^{23}$.

Manifest dotyczący rozejmu to wydarzenie bez precedensu, o ogromnej wadze dla kibiców, ze względu na to, od jak dawna istnieją spory między fanami niektórych klubów. Ukraińscy ultrasi dali najlepszy przykład całemu społeczeństwu, jak należy się porozumieć, pogodzić, zjednoczyć w trudnym dla kraju momencie. W komentarzach do oficjalnego tekstu deklaracji rozejmu jeden z kijowskich fanów słusznie napisał: „chcielibyśmy pokazać wszystkim, że jesteśmy przede wszystkim Ukraińcami i że istnieją rzeczy ważniejsze niż wojny piłkarskie" (Обіиійна заява всіх ультрас України з приводу останніх подій у краӥні 2014). Według Jewhena Zabaryly, autora artykułu pod wymownym tytułem Fanatyczni kibice piłkarscy — siła napędowa Rewolucji Godności,

przykładem prawdziwego ukraińskiego ducha jedności stała się zgoda kibiców różnych zespołów dla wspólnej walki z wrogiem. Wcześniej nigdy nie byli wzorem uczciwości. Od ich głosów i bębnów trzęsły się stadiony. Walczyli ze sobą bezlitośnie, łamiąc sobie nawzajem nosy i kończyny. Nazywano ich wojownikami stadionów piłkarskich i chuliganami. Zawsze byli postrachem dla policji i większości zwykłych ludzi. Ale to właśnie oni stali się bijącym sercem rewolucji, jego tarczą i mieczem. To oni jako pierwsi przybyli, by bronić pokojowych demonstrantów przed „tituszkami” i wilkołakami w mundurach, stali w pierwszych szeregach podczas ataku na pozycje Berkutu. [...] Co zatem sprawiło, że nieugięci wrogowie stanęli w jednym rzędzie? Odpowiedź jest prosta i oczywista - miłość do Ukrainy, patriotyzm w jego najbardziej szczerej formie. (Забарило 2015)

Kibice nie potraktowali ogłoszonego rozejmu jako deklaracji jedynie na papierze, od razu zaczęli go aktywnie realizować, organizując marsze jedności przed meczami każdej kolejki ukraińskiej ekstraklasy, organizując mecze i turnieje jedności (na przykład w mieście Stryj obwodu lwowskiego zapoczątkowany został turniej kibiców piłki nożnej pod hasłem Zachodnia jedność). Zimą 2013/2014 roku wśród wystroju sektorów kibicowskich na ukraińskich stadionach pojawiły się transparenty wspierające jedność kraju, w tym: W jedności siła!; Od Sanu do Donu - braterstwo i jedność!; Chwała Żołnierzom!; Wolność Ukrainy albo śmierć; W swoim domu swoja prawda, i moc, i wola; Jedyna, wolna, zjednoczona Ukraina!; Żółto-niebieskie flagi, jesteśmy niezwyciężeni - szable do góry!; Jesteśmy silni w naszej miłości do

23 Treść porozumienia w języku ukraińskim: „Ми, фанати українських футбольних клубів, заявляємо про наступне. В українському суспільстві зараз склалася дуже непроста ситуація. Зокрема, у деяких фанатських рухів вже почалися проблеми у своїх містах з органами „правопорядку” та місцевою „владою” виключно тому, що представники цих рухів публічно висловили свою мирну, громадянську позицію, на яку вони мають повне право. У зв'язку з цим ми вважаємо, що продовжувати будь-які протистояння між собою - це злочин, який зіграє проти нас же самих і в підсумку тільки погіршить сьогоднішню ситуацію в суспільстві. Враховуючи вищесказане, нами було прийнято рішення укласти перемир'я між рухами фанатів різних клубів на невизначений термін. Дане перемир'я включає в себе такі домовленості: 
Ukrainy; Zjednoczeni dla Ukrainy; Jedna, jedyna, zjednoczona Ukraina; Razem my - siła!; Zjednoczona Ukraina; Ukraina jedyna, Ukraina - jedyna, wolna, niepodzielna!; Ukraina - jedyna! Krym - to jest Ukraina!; Chłopaki Taurydy, jesteśmy $z$ wami! ${ }^{24}$. Podczas jednego ze wspólnych marszów kibiców charkowskiego Me-

- всі елементи „міського”, тобто спонтанного і не договірного навколофутболу знаходяться під забороною;

- заволодіння банерами, шарфами та іншими фанатськими атрибутами опонентів знаходиться під забороною;

- образливі банери, заряди на адресу один одного або міст-опонентів, командопонентів знаходяться під забороною;

- на трибунах здійснюється жорсткий контроль з метою не допустити появи шарфів з образами команд-опонентів, а також спалення шарфів команд-опонентів;

- під забороною знаходиться створення графіті з образами команд і рухів-опонентів, піар в Інтернеті існуючих подібних графіті, а також будь-яка графіті-війна між фанатськими рухами;

- здійснюється жорсткий контроль за тим, щоб виключити будь-які конфліктні ситуації з простими вболівальниками (не фанатами) команд-опонентів як на виїзних, так і на домашніх матчах.

Ці пункти $є$ основою основ майбутнього перемир'я. Рішення про перемир'я повністю підтримали лідери фанатських рухів наступних футбольних клубів: Прем'єр-ліга: Волинь Луцьк, Ворскла Полтава, Динамо Київ, Дніпро Дніпропетровськ, Закарпаття Ужгород, Зоря Луганськ, Карпати Львів, Металіст Харків (Південна і Північна трибуни), Металург Запоріжжя, Металург Маріуполь, ФК Севастополь, Таврія Сімферополь (Сектор 5 і Сектор 9), Чорноморець Одеса, Шахтар Донецьк.

Перша і Друга Ліги: Авангард Краматорськ, Буковина Чернівці, Десна Чернігів (Хлопці Північної Столиці і Ультрас Десна), Дніпро Черкаси, Енергія Нова Каховка, Зірка Кіровоград (червоно-жовті і жовто-зелені), Кристал Херсон, ФК Миколаїв, Нива Тернопіль, ФК Олександрія, Оболонь Київ, Поділля Хмельницький, Скала Стрий, Сталь Алчевськ, Сталь Дніпродзержинськ, ФК Суми, Титан Армянськ. Фанатські рухи аматорських ліг і без клубів: Кривбас Кривий Ріг, Нива Вінниця.

Ті рухи, з якими ми не встигли або не змогли зв'язатися, просимо підтримати нашу ініціативу і підтвердити готовність дотримуватися перемир'я по всіх перерахованих вище пунктах.

Крім цього вважаємо, що зараз відносини між нами повинні будуватися за принципом того, що ми всі в першу чергу - Українці. Тобто на першому місці повинні бути взаєморозуміння, довіра та взаємовиручка. Закликаємо всіх українських уболівальників, які не перебувають в жодних фанатських рухах (йдеться не лише про футбол), приєднатися до цього перемир'я і без агресії ставитися один до одного, незважаючи на те, які 6 протистояння не були між нашими командами на спортивних полях і майданчиках. [...] Саме тому ми вважаємо, що продовжувати будь-які конфронтації у фанатському середовищі в даний момент - злочин проти світлого майбутнього України. »Від Луганська до Карпат фанат фанату — друг і брат«. Слава Україні!” (Офіційна заява всіх ультрас України з приводу останніх подій у країні 2014).

${ }^{24}$ W języku ukraińskim: В єдності - сила!; Від Сяну до Дону - братерство, єдність, соборність!; Воїнам слава!; Воля Украӥни або смерть!; В своій хаті своя й правда, і сила, і воля; Єдина, вільна, соборна Україна!; Жовто-блакитні прапори, ми непереможні - шаблі догори!; Ми сильні нашою любов'ю до України!; Об'єднані заради Украйни, Одна, єдина, соборна Україна!; Разом ми - сила!; Соборна Україна; Україна єдина; Україна - єдина, вільна, неподільна!; Україна - єдина! Крим - ие Україна!, Хлопиі Тавриди, ми з вами! 
talista i donieckiego Szachtara 30 marca 2014 roku w Charkowie została po raz pierwszy wykonana Pieśn o Putinie, która dzięki Internetowi szybko stała się powszechnie znana, zyskała status ukraińskiej pieśni ludowej oraz uznanie w innych krajach. O fenomenalnym zjawisku popularności tego przeboju ukraiński pisarz Jurij Andruchowycz w wywiadzie dla „Radia Wolność” powiedział: „Na całym świecie śpiewają słynną piosenkę o Putinie. Jest to bardzo poważna klęska Rosji w wojnie propagandowej" 25 . Pieśń o Putinie, jak również inne dawne teksty składające się na folklor kibiców, w tym recytacje: Chwała Ukrainie! Bohaterom Chwała! Chwała narodowi! Śmierć wrogom! Ukraina ponad wszystko!; Kto nie skacze, ten Moskal; Razem i do końca! ${ }^{26}$, które rozbrzmiewały na ulicach ukraińskich miast pod koniec roku 2013 i na początku 2014, skojarzone zostały przede wszystkim z wydarzeniami społeczno-politycznymi w kraju, a nie z ruchem ultrasów.

Kiedy zaczęła się wojna z Rosją, wielu kibiców futbolu wstąpiło w szeregi ochotniczych batalionów. Przedstawiciele ukraińskich kibiców po dziś dzień bronią państwa, będąc członkami Gwardii Narodowej, batalionów „Dniepr”, „Azow”, „Ajdar” itd. Kibice jako wolontariusze zorganizowali także masowe akcje poparcia dla armii (Кабанюк 2016).

W ciągu trwającego ponad dwa lata rozejmu nie doszło między kibicami do żadnej bójki czy werbalnego znieważania przeciwnika. Fanatycy piłkarscy dotrzymują danego sobie słowa i potwierdzają swoje obietnice czynem. W czasie wojny uległy transformacji, dopasowując się do nowych warunków społeczno-politycznych, także dawne teksty kibicowskie. Na przykład piosenka: „Bij w bęben, bij w bęben, bij w bęben, bij w bęben, bij w bęben, trąbcie trąby, całuj dziewczynę w same usta i puchar pełny nalewaj" 27 , za pomocą której dawano osobie wybijającej rytm na bębnie sygnał, aby zwiększyła częstotliwość uderzeń, otrzymała nowe, następujące brzmienie: „Bij w Moskala, bij w Moskala, bij w Moskala, bij w Moskala, bij w Moskala, układaj trupy i karabin maszynowy bierz do ręki, i nowy z nabojami zakładaj pas!”28.

Podsumowując, warto podkreślić, że potrzeba badań poświęconych zmianie retoryki kibiców piłki nożnej spowodowana została aktualnością samych wydarzeń społeczno-politycznych na Ukrainie w ostatnich latach. Narodowa Rewolucja Godności oraz agresja rosyjska na południu i wschodzie Ukrainy stały się bodźcem do transformacji werbalnego i niewerbalnego zachowania ukraińskich ultrasów, a ogłoszenie na nieokreślony termin rozejmu między kibicami wszystkich klubów jest przykładem konstruktywnego działania trwającego do dziś. Zmianę nastawie-

${ }^{25}$ Jurij Andruchowycz. Wywiad dla „Radia Wolność” 16 maja 2016 roku, https://www. radiosvoboda.org/ (dostęp: 16.05.2016).

26 W języku ukraińskim: Слава Україні! - Героям слава! Слава нації! - Смерть ворогам! Україна понад усе!, Хто не скаче, той москаль, Разом і до кіния!

27 W języku ukraińskim.: Бий барабан, бий барабан, бий барабан, бий барабан, бий барабан, лунайте труби, цілуй дівчину просто в губи і келих повний наливай.

28 W języku ukraińskim: Бий москаля, бий москаля, бий москаля, бий москаля, бий москаля, складайте трупи і кулемет беріть у руки, і нову ленту заряджай! 
nia społeczeństwa ukraińskiego wobec kibiców wyraźnie odzwierciedla wypowiedź lwowskiego dziennikarza Otara Dowżenki na portalu społecznościowym: „Przed rewolucją kibice futbolu wydawali mi się wrogim, agresywnym środowiskiem. Teraz - są rodzajem aniołów"29. Wydarzenia na Ukrainie w latach 2014-2016 przyczyniły się do innego spojrzenia Ukraińców na środowisko kibicowskie oraz pozwoliły dostrzec w nim konstruktywną siłę.

Przełożyła Iryna Procyk

\section{Bibliografia}

Білан Б. (2014): Нашими діями ми можемо змінити Україну, - ультрас, http://zik.ua/ua/ news/2014/01/31/nashymy_diyamy_my_mozhemo_zminyty_ukrainu_ultras_ 457443 (dostęp: 25.01.2014).

Жадан С. (2011), Білі футболки, чорні труси, [w:] Письменники про футбол. Літературна збірна України, укладач С. Жадан, Харків, с. 76-106.

Забарило Є. (2015): Футбольні фанати - рушійна сила Революиії гідності, http://uapatriot.org/ ua/novini/novini/futbolnifanatyrushiinasylarevoliutsiihidnosti.html (dostęp: 15.07.2015).

Кабанюк I. (2016): Немаєдругоїкраїни, Немаєіншого „Дніпра”. Маршєдностіу Дніпропетровську, http://glavnoe.dp.ua/blogs/nemaye-drugoyi-krayiny-nemaye-inshogo-dnipra.-marsh-hidnosti-u-dnipropetrovsku (dostęp: 17.03.2016).

Обіиійна заява всіх ультрас України з приводу останніх подій у країні, http://1927.kiev.ua/news/

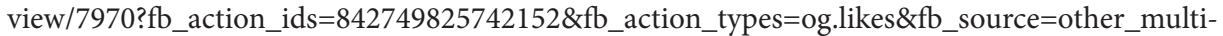
line\&action_object_map $=\{\% 22842749825742152 \% 22 \% 3$ A1437562673146851 $\} \&$ action_type_map $=\{\% 22842749825742152 \% 22 \% 3 \mathrm{~A} \% 220$ g.likes\%22\}\&action_ref_map (dostęp: 13.02.2014).

Процик I. (2014): Ми не вороги - ми українці. Українські футбольні ультрас під час революціі гідності, „Типологія та функції мовних одиниць”, № 2, с. 234-248.

Щур М. (2014): Украӥнські ультрас здивували своєю громадянською позииією, - німецький дослідник, http://www.radiosvoboda.org/content/article/ 25253108.html (dostęp: 4.02.2014).

http://www.ultras.org.ua (2013-2016).

\section{Change of rhetoric of Ukrainian football fans during social and political events in Ukraine in 2013-2016}

Summary

In Ukrainian society football fans environment is usually perceived in a negative way - first of all due to its characteristic verbal aggression and rude behavior at the stadiums and beyond them. In Ukraine, like in all the other European countries, movements of football fans have never been aside

29 Otar Dovzhenko. Facebook. Luty 2014, https://www.facebook.com/otardovzhenko. 
from politics: they always emphasized their national identity, actively reacted to social and political events in the country, declared aggressive attitude towards fan movements which professed left views. Change of verbal aggression and traditionally hostile attitude towards rival fan groups happened in fans environment in 2013-2014, when in Ukraine Revolution of Dignity took place and fans were the first to defend its values. February 13, 2014 Manifesto of football fans was publicized which bears witness to transformation of traditional rhetoric of fans. Provisions of the Manifesto under the name of "A fan to another fan is like a brother and a friend from Luhansk to the Carpathians" which say about establishing of an open-ended truce among Ukrainian football ultras still hold. The aim of the article is to present change of verbal and non-verbal behaviour of Ukrainian football fans during social and political events in Ukraine in 2013-2016 and to give the examples of texts from the discourse of football fans which have become commonly recognized mottos and songs during Maidan and Russian aggression in Ukraine during 2014-2016.

Keywords: social and political events in Ukraine, football fans, verbal and non-verbal behaviour, verbal aggression, change of rhetoric. 